\title{
The inhibitory effectiveness of ethanol extract of selasih leaves towards Streptococcus sanguis growth
}

\author{
Ivhatry Rizky Octavia Putri Susilo*, Mieke Hemiawati*, Ame Suciati* \\ *Department of Oral Biology Faculty Of Dentistry Universitas Padjadjaran
}

\begin{abstract}
Introduction: Selasih is one of tropical and subtropical plant used as traditional medicine. It has antibacterial activity especially toward Gram-positive bacteria because it contains volatile oils, tannin, flavonoid and tertepenoid. Method: The study was performed as an experimental laboratory study used Kirby Bauer agar diffusion applied to eight samples of Streptococcus sanguis which was done by twice repetition for each sample. The concentrations of ethanol extract were $16 \%, 8 \%, 4 \%, 2 \%$ and $1 \%$.The result was analysed using ANOVA method for single factor of experimental design. The result of the study showed that there was evidence of the antibacterial effect contained in the ethanol extract of selasih leaves inhibiting the growth of Streptococcus sanguis. The average of inhibitory zone for each concentration in every sample, were: $5,25 \mathrm{~mm}$ for $16 \%, 3,22 \mathrm{~mm}$ for $8 \%, 1,84 \mathrm{~mm}$ for $4 \%, 1,53 \mathrm{~mm}$ for $2 \%$ and $0,19 \mathrm{~mm}$ for $1 \%$. The conclusion of the study indicates that there is an antibacterial effects in ethanol extract of selasih leaves (Ocimum basilicum Linn) which inhibits the growth of Streptococcus sanguis. This antibacterial strength is caused by the active content of selasih leaves extract.Conclusion: The extract of basilicum ethanol (Ocimum basilicum L) effectively inhibits the growth of Streptococcus sanguis.
\end{abstract}

Keywords: Antimicrobial effect, Selasih (Ocimum Basilicum Linn) Ethanol Extract, Streptococcus sanguis

\section{INTRODUCTION}

The use of plants as a traditional medicine has long been accepted in almost all countries in the world. Traditional medicine is used as a complementary treatment in Asian, African and Latin American countries.(1) The benefits of herbal plants in Indonesia as the basic ingredients for the manufacture of drugs are efficient, cheap, easy to obtain, and safe because they have relatively lower side effects, so herbs can used for preventive, curative, and rehabilitative purposes in the health sector. (2)

One of the plants that can be used as a traditional medicine is basilicum leaf (Ocimum basilicum L.). Ocimum is a type of group of tropical and subtropical plants in the world. Ocimum genus consists of $50-150$ species that have a distinctive aroma and have been used for years as wild herbaceous plants originating from Asia, Africa, Central and South America, so it can be concluded that basil can grow invarious parts of the world. $(3,4)$

Basil leaves are reported to have medical activity and treat more than a few conditions such as analgesic, antihelmintic, antibacterial, antifungal, anti-inflammatory, anti-oxidant, anti-stress, antithyroid, antitussive, anti-ulcer and anticancer. (3-6) According to Moghaddam (7), extract Basil 
leaves have antibacterial activity against Gram positive bacteria such as Staphylococcus aureus and Streptococcus ssp; Gram-negative bacteria such as Shigella, Salmonella, Bacillus cereus, E. coli, and P.euriginosa. (7) This is because the content of the active compound therein, one of these compounds is essential oil. In addition to essential oils, the content contained in the leaves basil is tannin, flavonoid, and terpenoid. $(8,9)$

The discovery of this basilleafcanincrease the utilization of plants into medicinal plants that one efficacious as antibacterial. This will benefit health.

Basil leaf extract with ethanol solvent, hexane and methanol can inhibit the growth of 146 microorganisms consisting of bacteria, fungi and yeast. The minimal inhibitory concentration with ethanol and hexane solvents was 125$250 \mu \mathrm{l} / \mathrm{ml}$ while the solvent was $62.5-500 \mu \mathrm{l} /$ $\mathrm{ml}$. (3) The extract of ethanol leaves basil can fight Staphylococcus aureus bacteria with $8 \mathrm{~mm}$ diameter at concentrations of $20 \mu \mathrm{l}, 9 \mathrm{~mm}$ at 40 $\mu \mathrm{l}$, and $10 \mathrm{~mm}$ at $60 \mu \mathrm{l}$. (10) Ethanol extract of basil leaves has activity to inhibit the growth of Bacillus sereus and Bacillus subtilitis bacteria at $10 \mathrm{mg} /$ disc concentration, Micrococcus luteus at concentration $5 \mathrm{mg} / \mathrm{disc}$ and Staphylococcus aureus at concentration 20mg / disc (11).

According to the study (12), the extract of basil leaves of the tulsi type from concentration of $10 \%$ to $0.5 \%$ which has the maximum ability to inhibit the growth of Streptococcus mutans ie at $4 \%$ concentration level with $22 \mathrm{~mm}$ inhibition zone. In general, the study stated that the extract of basil leaves (Ocimum basilicum) has antibacterial power against Gram positive bacteria. Streptococcus sanguis has similar characteristics with Streptococcus mutans and Staphylococcus aureus, ie Gram-positive bacteria, normal flora of the oral cavity. Streptococcus sanguis belongs to the a-Streptococcus group found on the tooth surface including inside and including pioneers in plaque formation. Attachment ability on tooth surface is bigger than other bacteria. This is because on the surface of the tooth, the bacteria are attached to be mediated by a thin layer of salivary protein and glycoproteins covering the tooth surface known as the pellicle.

Prevention of early plaque formation is necessary to reduce or inhibit the amount of Streptococcus sanguis in the oral cavity by mechanical means or in combination with chemicals such as the use of mouthwashes, one of them with natural antibacterial ingredients.(13-16) This study aims to determine the antibacterial power of leaves of basil as an alternative natural ingredient to inhibit or kill the growth of bacteria.

\section{METHODS}

This research is experimental laboratory that is test of ethanol extract of basilicum leaf (Ocimum basilicum L.) to the growth of Streptococcus sanguis bacteria isolated from saliva of FKG UNPAD student by using agar diffusion method.

The population is the leaf of basil originating from West Java and its sample is the basil leaf from Lembang. The tool needed in this research is scales, test tube, reaction tube rack, Petri dish, pipette, paper, inoculation device (oase and needle), glass object, eksikator, candle, cotton, microscope, incubator, spirtus lamp, perforator diameter $10 \mu \mathrm{m}$ and ruler or steering range.

For the breeding medium is used Plate Agar Blood (LAD), $0.9 \% \mathrm{NaCl}$ solution and glucose bulyon. Sugar medium for bacterial identification is insulin, ranifose, $\mathrm{H} 2 \mathrm{O} 23 \%$ and gram staining material consisting of Gentian Violet carbolic, lugol solution, Fuhsin solution and $95 \%$ alcohol. As the test bacteria is used isolate Streptococcus sanguis isolated from saliva student FKG 2008.

\section{RESULTS}

The result of incubation culture of saliva on the Lamb for Lamb for 24 hours at $37^{\circ} \mathrm{C}$ in anaerobic facultative atmosphere showed the growth of different bacterial colonies. Some colonies show hemolysis reactions that show the formation of green zones around bacterial colonies, indicating that the bacteria can only reduce $\mathrm{Hb}$ (hemoglobin) in erythrocytes to metHb (methemoglobin), which is characteristic of Streptococcus a hemolyticus.

The bacterial colony was performed by gram staining and microscopically studied with $10 \times 100$ magnification. Examination shows Gram positive coccus with chain formation. The description shows the allegation that the colony is Streptococcus ssp.

Identification of bacterial colonies showed negative results with $3 \% \mathrm{H} 2 \mathrm{O} 2$ solution ie no gas 
bubbles in bacterial suspension. This suggests a suspicion that the colony is Streptococcus rather than Staphylococcus because Streptococcus has no catalase enzyme to convert $\mathrm{H} 2 \mathrm{O} 2$ into $\mathrm{H} 2 \mathrm{O}$ and $\mathrm{O} 2$.

Identification through biochemical tests, bacteria on medium containing red phenol in the form of ranifose do not show any change of color to yellow, where the color of medium remain red. So these results indicate that the fermentation test results are negative because these bacteria do not ferment carbohydrates. The insulin medium exhibits a color change in which the medium changes from red to yellow because the bacteria ferment insulin carbohydrates and produce acids. This acid changes the red indicator color to yellow. The hemodigestion colony can be summed up as Streptococcus sanguis. $(17,18)$

Examination of inhibitory power of ethanol extract of the liver leaves on Streptococcus sanguis using agar diffusion method, which was incubated for 24 hours at $37^{\circ} \mathrm{C}$, produced an inhibitory area in culture. The resistor area is seen as a clear, non-overlapping area of test bacteria around the ethanol extract of basil leaves. This shows that the extract of ethanol leaves basil has antibacterial inhibitory power to Streptococcus sanguis.

Based on the research that has been done, obtained the results of data calculation of the resistor area of each sample. The inhibitory areas were tabulated and tested statistically in the form of minimum values, maximum values, mean, mode, median, and standard deviations of the number of basil extracts with various concentrations of 8 (eight) samples available. Statistic result using ANAVA i

The results showed that average of the inhibitory area of each sample. it was found that at a concentration of $16 \%$ the drag area decreased in the 2nd sample, 3 and increased again in the 4th sample, after which it decreased steadily to sample 7 and increased again in the sample to 8 . Similarly, for konsetrasi $4 \%, 2 \%$, and $1 \%$ decreased as concentration $16 \%$. This indicates that the concentration has an effect on the inhibitory area of each sample. This means that the greater the concentration the larger the inhibition diameter.

\section{DISCUSSION}

This study was conducted to test the antibacterial effect of extracts of betasih leaf (Ocimum basilicum L.) to Streptococcus sanguis. Based on their metabolite content, the basilicum $L$ plant contains the essential oils, flavanoid, tertepenoid and tannin, which have antibacterial activity. (19)

Bacterial cells are protected by cell walls consisting of peptidoglycan composed by $\mathrm{N}$-acetylglucosamine and $\mathrm{N}$-acetylmuramate bonded to each other and other amino acids. (20) Streptococcus sanguis is a gram-positive bacterium having 40 peptidoglycan layers, most of which are the building blocks bacterial cells. Any substance that inhibits one of the peptidoglycan biosynthesis steps, the growing cell wall weakens and lysis occurs. (14) Gram positive bacteria do not contain an outer membrane that serves as a barrier so that hydrophobic and hydrophilic antibacterial compounds can pass through. Cell membranes with impaired permeability will not die but are suspected to slow down the metabolic processes in cells that inhibit cell growth. (4) Therefore Streptococcus sanguis, if exposed to a substance, inhibits its cell growth. Essential oils can inhibit the action of enzymes involved in energy production and the formation of structural components so that the formation of cell walls is disrupted. Lipophilic component contained in the cell wall or cell membrane can be changed due to the use of antibacterial compound so that the composition of the cell wall is not dissociated. The essential oil of basil leaves contains eugenol belonging to phenol compounds that have antiseptic effect and works by damaging cell membranes.

Antibacterial mechanisms that may occur due to the binding of phenol compounds with bacterial cells that would interfere with membrane permeability and transport process. $(4,20)$ Phenol compounds are lipophilic that can interfere with the integrity of cell membranes because of the lipid molecules that will cause cell membrane damage through the mechanism of surface tension reduction and increase the permeability and loss of the basic structure of the constituent elements by disrupting the phospholipid layer.

The impaired phospholipid layer causes changes in fatty acid composition resulting in cell swelling and the permeability defenses will become weak and damaged. Osmotic pressure in the cells will become sensitive and cause the discharge of 
Figure 1 Streptococcus Gram Staining

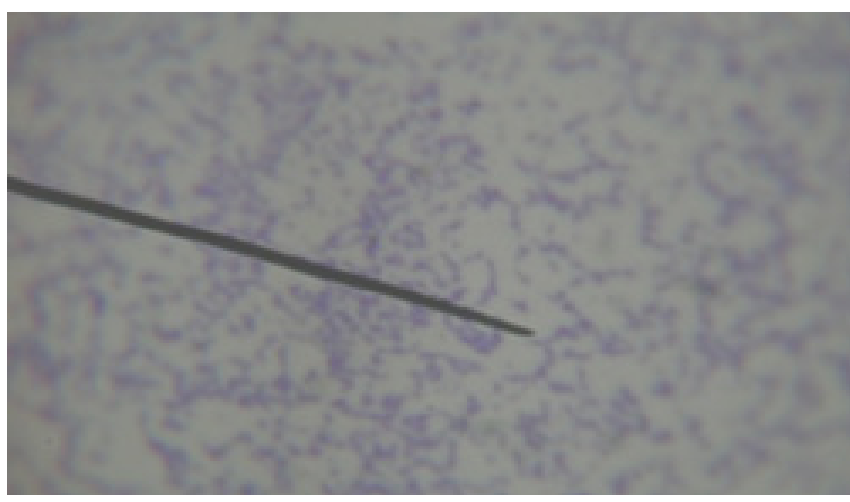

Figure 2 Streptococcus sanguis biochemical identification result

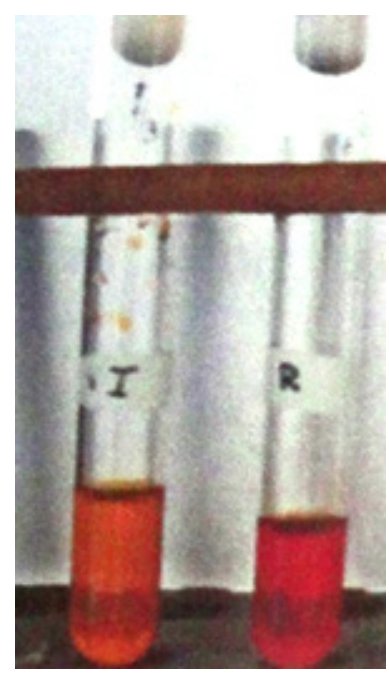

Figure 3 Streptococcus sanguis culture

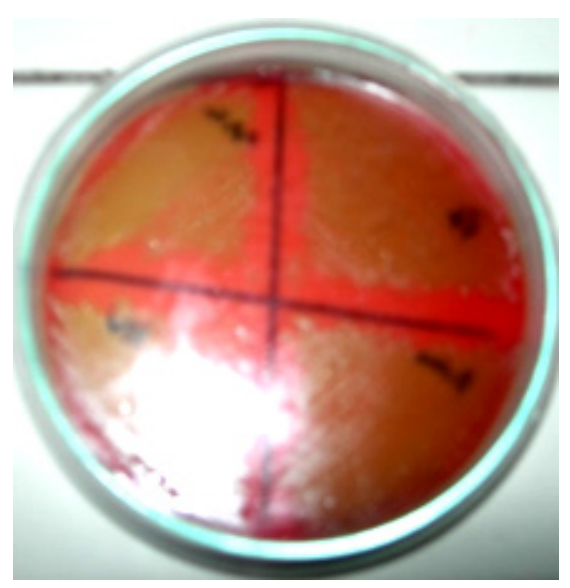

Table 1 Results Average area of inhibitory area of concentrations of $16 \%, 8 \%, 4 \%, 2 \%$ and $1 \%$ leaf extract of basil to Streptococcus sanguis 


\begin{tabular}{ccccccc}
\hline Average Area of Inhibition $(\mathrm{mm})$ in concentration & & & & & & \\
\hline No. & $\mathbf{1 6 \%}$ & $\mathbf{8} \%$ & $\mathbf{4} \%$ & $\mathbf{2 \%}$ & $\mathbf{1} \%$ & Total \\
\hline 1 & 5,75 & 3,17 & 1,67 & 1,79 & 0 & \\
2 & 5,27 & 2,93 & 1,37 & 1,32 & 0,13 & \\
3 & 5,08 & 2,96 & 2,27 & 2,32 & 0,62 & \\
4 & 4,97 & 3,67 & 2,87 & 2,04 & 0,38 & \\
5 & 5,75 & 3,17 & 1,67 & 1,79 & 0 & \\
6 & 5,04 & 2,93 & 1,37 & 1,32 & 0,13 \\
7 & 4,58 & 3,34 & 1,42 & 0,74 & 0 & \\
8 & 5,58 & 3,62 & 2,13 & 0,95 & 0,28 & \\
\hline Total & 42,02 & $\mathbf{2 5 , 7 8}$ & $\mathbf{1 4 , 7 6}$ & $\mathbf{1 2 , 2 6}$ & $\mathbf{1 , 5 3}$ & $\mathbf{9 6 , 3 4}$ \\
Average & $\mathbf{5 , 2 5}$ & $\mathbf{3 , 2 2}$ & $\mathbf{1 , 8 5}$ & $\mathbf{1 , 5 3}$ & $\mathbf{0 , 1 9}$ \\
\hline
\end{tabular}

bacterial cell components such as proteins, nucleic acids, nucleotides and others so as to inhibit metabolism and transport of substances. This results in the loss of cations and macromolecules from cells. (21-24) At low concentrations of phenol compounds will cause protein denaturation. Most phenolic molecules are not dissociated, are more hydrophobic and dissolve in the lipid phase of the lipid cell membrane, the better their antibacterial ability. $(4,19,23,25)$ Therefore, Essential oils and phenol compounds can disrupt cell wall components and permeability of cell membranes.

The antibacterial activity of tannins by forming complexes with bacterial substrates by passing through the cell wall of bacteria to reach the cell membrane. The bacterial cell wall contains polysaccharides and different proteins that allow part of the tannin to enter. The tannin group has more than two o-diphenol groups in its molecule, which can form complexes with metal ions such as $\mathrm{Cu}$ and Fe so that tannins can reduce the availability of essential metal ions for bacteria. $(26,27)$ The flavonoid antibacterial mechanism by inhibiting nucleic acid cystesis, inhibits membrane function cytoplasm and energy metabolism.

The bacterial cytoplasm membrane itself serves to regulate the entry of food ingredients or nutrients, if the cytoplasmic membrane is damaged then the important metabolites in the bacteria will come out and the foodstuff to produce energy can not enter so that the inability of bacterial cells to grow. (28) Therefore, tannins and flavonoids can disrupt cell growth that can cause cell death.

Based on the above explanation, it can be assumed that the ethanol extract of basil leaves has antibacterial activity can be used as the basic ingredient of mouthwash because it has mechanisms such as destroying and depositing bacterial cell walls and can inhibit bacterial attachment to the tooth surface. The ethanol extract of basil leaves can inhibit the growth of positive gram bacteria such as Streptococcus sanguis which is the pioneer bacterium of plaque formation.

\section{CONCLUSION}

The extract of basilicum ethanol (Ocimum basilicum L) effectively inhibits the growth of Streptococcus sanguis.

\section{REFERENCES}

1. Oktora L. Pemanfaatan obat tradisional dengan pertimbangan manfaat dan keamananny.Majalah Ilmu Kefarmasian. J Far. Dec 2006;3(1):1-7 pp.

2. Nugroho I. Tanaman obat indonesia. APFROGEN News Letter edition. $2^{\text {nd }}$ Ed. Implementasi Program Pengelolaan dan Konservasi Sumberdaya Genetik Hutan di Tingkat Nasional. 2010.

3. Adiguzel A, Guluce M, Sengul M, Ogutcu H, F. Sahin I, Karaman. Antimicrobial effects of ocimum basilicum (labiateae) extract. Turkey: J. Biol. Turk 2005;29(2):155-160.

4. Maryati SR, Fauzia T, Rahayu. Uji aktivitas antibakteri minyak atsiri daun kemangi (Ocimum basillum L.) terhadap Staphylococcus aureus dan Escherichia coli. Jurnal Penelitian Sains \& Teknologi. 2007;8(1):30-38. 
5. Hadipoentyanti E. Wahyuni S. Keragaman selasih (Ocimum Spp.) berdasarkan karakter morfologi, produksi, dan mutu herba. Jurnal Littri. 2008;14(4):141-148.

6. Sullivan, C. Food For Thought: The Science, Culture, \& Politics of Food in Spring. 2009.

7. Moghaddam AMD, Shayegh J, Mikaili P, Sharaf JD. Antimicrobial activity of essential oil extract of Ocimum basilicum L. leaves on a variety of pathogenic bacteria. Iran: J Med Plants Res. 2011;5(15):3453-3456.

8. Lachowicz KJ, Jones GP, Briggs DR, Bienvenu FE. Wan WA, Covertry MJ. The synergistic preservative effects of the essential oil of sweet basil (ocimum basilicum () againts acid tolerant microflora. Lett Appl Microbiol. 1998;209-214pp.

9. Agusta A. Minyak Atsiri Tumbuhan Tropika. ITB: Bandung. 2008. 29-34 pp.

10. Durga RK, Karthikumar S, Jegatheesan K. Isolation of potential antibacterial and antioxidant compounds from acalypha indica and ocimum basilicum. African J Plant Sci. 2010;4(5):163-166.

11. Ahmad A, Arifin H. Aktifitas antimikroba ekstrak ethanol daun selasih (Ocimum basilicum L). J Mat Peng Alam. 1995;4(1):74-82.

12. Argawal $P$, Murlikrishnan, Nagesh L. Evaluation of the antimicrobial activity of various concentrations of tulsi (Ocimum sanctum) extract against Streptococcus mutans: $A n$ in vitro study. Indian J Dent Res. 2010;21(1):357-9.

13. Samaranayake LP. Essential Microbiology for Dentistry . $2^{\text {nd }}$ Ed. London,Churchill Livingstone. 2002.

14. Jawetz E, Melnick JL, Adelberg EA. Medical MicrobiologiEdition 23, Lange: Brooks Md. 2005.

15. Carranza FA, Newman MG. Clinical Periodontology $10^{\text {th }}$ ed. Philadelphia: WB Sounders Co. 2006. 141-143,728 pp.

16. Yamaguchi M, Terao Y, Ogawa T, Takahashi T, Hamada S, Kawabata S. "Role of streptococcus sanguinis sortase A in bacterial colonization."
Microbes and Infection. 2006;6(8):2791-96.

17. Capucino G, James G. Sherman N. Microbiology: A Laboratory manual, $6^{\text {th }}$ Ed. Bejamin Cummings. London: San Fransisco. 2006.

18. Lamount RJ, Lantz MS, Burne RA, Leblanc DJ. Oral Microbiology and Immunology, American Society for Microbiology, Washington DC. 2006. 53-55,119,253pp.

19. Muafia S, Shaista JK, Nuzhat HK. Study of antioxidant and antimicrobial activity of sweet basil (ocimum basilicum) essential oil. Biotechnology and food research centre, pcsir laboratories complex. pharmacologyonline. 2011;1:(1)105-111.

20. Pratiwi S. Mikrobiologi Farmasi. Yogyakarta: UGM Erlangga. 2008.

21. Schleifer KH, Kandler $O$. Peptidoglycan types of bacterial cell walls and their taxonomic implications. Bacteriol Rev. 1972. 36:407-477.

22. Neuhaus FC, Baddiley J. A continuum of anionic charge: Structures and functions of D-alanylteichoic acids in gram-positive bacteria. Microbiol Mol Biol Rev. 2007;67(2):686-723.

23. AdolfAJN. Kajianmekanismeantibakteriekstrak andaliman (zancthoxylum acanthopodium dc) terhadap bakteri patogen pangan. Bogor. Tesis program pascasarjana IPB. 2006.

24. Weidenmaier $C$, Peschel A. Teichoic acids and related cell-wall glycopolymers in Grampositive physiology and host interactions. Nat Rev Microbiol. 2008. 6:276-287.

25. Lewis K, Salyers AA, Taber HW, Wax RG. Bacterial resistance to Antimicrobial. Marcel Dekker,Inc. 2004.

26. Scalbert A. Antimicrobial Properties of Tanins. Review Article Number 63 Phytochemistry. 1991;30(12):3875-3883.

27. Hagerman, AE. Tannin Chemistry. Oxford.Universitas Miami Department Chemistry and Biochemistry. 2002.

28. Tim CTP, Lamb AJ. Antimicrobial Activity of Flavonoid. International. Journal of Antimicrobial Agent. 2005. 26343-356. 
